\title{
CONTRIBUTION OF WATER EROSION TO COASTAL SEDIMENTARY MORPHODYNAMICS: QUANTIFICATION USING UNIVERSAL SOIL LOSS (RUSLE) IN THE KAFOUNTINE WATERSHED (SOUTHERN SENEGAL)
}

\author{
Dome TINE ${ }^{1}$, Mbagnick FAYE ${ }^{2}$, Mamadou THIOR ${ }^{3}$, Modou MBAYE ${ }^{4}$, Landing BIAYE ${ }^{5}$, Gayane FAYE ${ }^{6}$, \\ Djibril TINE ${ }^{7}$ \\ ${ }^{1}$ Department of Geography, Associate Researcher at the Applied Remote Sensing Laboratory (LTA) - Institute of \\ Earth Sciences (IST), Cheikh Anta DIOP University, Dakar, Senegal \\ ${ }^{2}$ Laboratory of Climatology and Environment (LCE) - Department of Geography, Cheikh Anta DIOP University, \\ Dakar, Senegal \\ ${ }^{3}$ Laboratory of Geomatics and Environment (LGE), Assane SECK University, Ziguinchor, Sénégal \\ ${ }^{4}$ Applied Remote Sensing Laboratory (LTA) - Institute of Earth Sciences (IST), Cheikh Anta DIOP University, \\ Dakar, Senegal \\ ${ }^{5}$ Pedology laboratory, Institute of Earth Sciences (IST), Faculty of Science and Technology, Cheikh Anta Diop \\ University, Dakar, Senegal \\ ${ }^{6}$ Applied Remote Sensing Laboratory (LTA) - Institute of Earth Sciences (IST), Cheikh Anta DIOP University, \\ Dakar, Senegal \\ ${ }^{7}$ Applied Remote Sensing Laboratory (LTA) - Institute of Earth Sciences (IST), Cheikh Anta DIOP University, \\ Dakar, Senegal
}

https://doi.org/10.35410/IJAEB.2020.5586

Corespondance author: dometine85@gmail.com

\begin{abstract}
Lower Casamance is characterized by a set of watersheds drained by permanent streams that flow directly to their mouths. Among these watersheds, we have Kafountine, which, like all others, participates in the sedimentary morphodynamics of the coastline through the water erosion that occurs especially upstream, on the slopes. The sediments transported and deposited are usually composed of fine sands forming accumulations in places that stabilize the beaches. The objective of this study is to estimate the amount of sediment eroded in the Kafountine watershed and transported to the coast. To do this, we used the Wischmeier and Smith Universal Soil Loss Equation (RUSLE) (1978), which is frequently used to calculate the average annual soil loss per unit of land resulting from slick and channel erosion. The equation is applied after the data is integrated into a Geographic Information System (GIS). The results from the overlapping of factors tell us that the Kafountine watershed is losing on average $54.5 \mathrm{t} / \mathrm{ha} / \mathrm{an}$.
\end{abstract}

Keywords: Erosion; sedimentary morphodynamics; RUSLE; Watershed; Kafountine.

\section{INTRODUCTION}

Water erosion is an environmental issue that particularly affects the southern region of Senegal. The abundance of rainfall during the rainy season causes water erosion and causes the degradation of the watershed's vegetation cover. Impacts include a decrease in the thickness and fertility of the arable layer, whose severity depends on the rate of erosion and soil thickness, but also on the nature of the substrate [1].The northern coastal fringe of the Southern Rivers is 
characterized by generally sandy coastlines that depend on sedimentary inputs from watersheds because of heavy rainfall resulting in water erosion and significant sediment transport to the mouths. The intensification of precipitation predicted by the Intergovernmental Panel on Climate Change [2] will result in the degradation of the surface layers of soil cover and the displacement of the materials that make up it. These sedimentary particles detached upstream from watersheds are drained to the shoreline where they participate in beach morphodynamics and marine sedimentology. Water erosion is thus a factor in the degradation of cropland but also a provider of sediment to the coast, slowing coastal erosion and creating sedimentary stocks in places [3].

The Kafountine watershed is marked by mismarked river systems controlled by topographical factors, sedimentary load transported, drainage system size, shoreline stability through vegetation, climate, and tectonics $[4,5]$. With a turbulent flow in the main channel, these streams can carry a significant sediment load towards the beach. Thus, the nature of coastal sediments tells us about their geological origin, while the mapping of marine sediments highlights the granulometry of mobilizable particles (composed mainly of sands and fine sand).

The problem of quantifying sediment detached and transported by water was solved with the introduction of the Universal Soil Loss Equation (USLE) developed in 1960 and updated in 1978 by Wischmeier and Smith of the US Department of Agriculture. This Universal Soil Loss Equation (USLE) was revised (RUSLE) before becoming an improved version of USLE based on new technology. New methods are introduced to evaluate the values of the various factors in the model [6]. The model predicts the long-term average annual rate of eroded sediment at a watershed scale as a function of rainfall, soil type, topography, crop rotation and crop management techniques. These different elements, called factors, constitute the parameters that define the nature and intensity of the erosion process. Soil saturation leads to runoff, detachment and transport of sediment particles. The possibility of modelling water erosion is therefore dependent on the one hand on the existence of spatialised data describing these factors, and on the other hand on the existence of operational models capable of describing the processes and evaluating the intensity of erosion on the basis of the available data [7 ].

Remote sensing associated with geographic information systems (GIS) allows thematic maps to be developed for each of the erosion factors. Crossing these maps provides a map of soil losses at any point in the study environment [8]. The evaluation of the model consists of validating the different thematic maps produced for the application of the model. GIS is now an essential tool in the management of natural resources. To assess risks or establish management patterns for soil conservation, the use of modelling is a decision-making tool. This process allows us today to understand soil degradation processes and all the factors involved in them and to predict future impacts considering changes in the physical characteristics of the environment.

\section{STUDY AREA}

The Kafountine watershed is located between $12^{\circ} 48^{\prime}$ and $13^{\circ} 12^{\prime}$ North latitude and $17^{\circ} 00^{\prime}$ and $15^{\circ} 48^{\prime}$ West longitude (Figure 1). It is in the Ziguinchor region of Lower Casamance and covers a large part of the Kafountine town of which it bears its name. It is drained by a water system 
and streams whose river flow is influenced by seasonal precipitation dynamics. From a geological and geomorphological point of view, Casamance belongs to the SenegaleseMauritanian sedimentary basin. The latter was established in the Jurassic with the opening of the central Atlantic. It is of Meso-Cenozoic age and is based on a Precambrian substrate at Paleozoic [9]. It stretches from Cap Blanc in Mauritania to Cape Roxo in northern Guinea Bissau. The sediments are characterized by coarse detritus under the coastal influence on the east and become increasingly thin to the west under marine influence. Sedimentary materials consist mainly of sand, clay and marl alternating with limestone [5]. From a climatic point of view, the region belongs to the South Sudan coastal domain. It is marked by quite high temperatures varying according to the seasons. Rainfall is more than $1000 \mathrm{~mm}$ per year. The seasonal cycle is very contrasted with a long dry season that lasts almost seven (7) months (November to May) and a short rainy season that extends over five (5) months (June to October), [10].

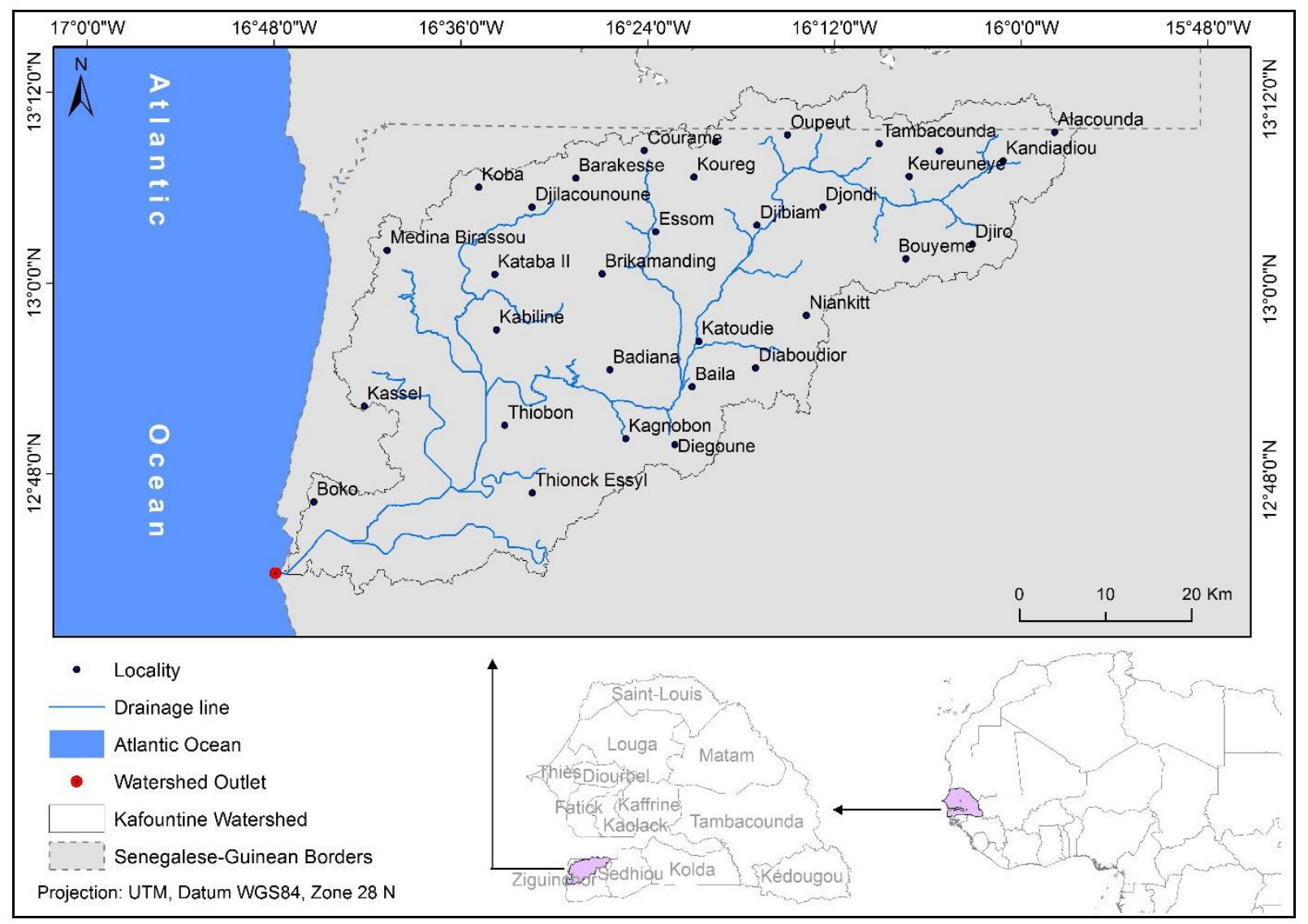

Figure 1: Geographical location of Kafountine Watershed.

Erosion depends on several climatic factors, but rainfall remains the most important in the continental environment. Although it is the most watered region of Senegal, Natural Casamance is exposed to the adverse effects of climate change and degradation of natural resources due to poor spatial-temporal distribution of precipitation (Figure 2). Soil saturation noted in August favor's runoff and erosion on the slopes. 


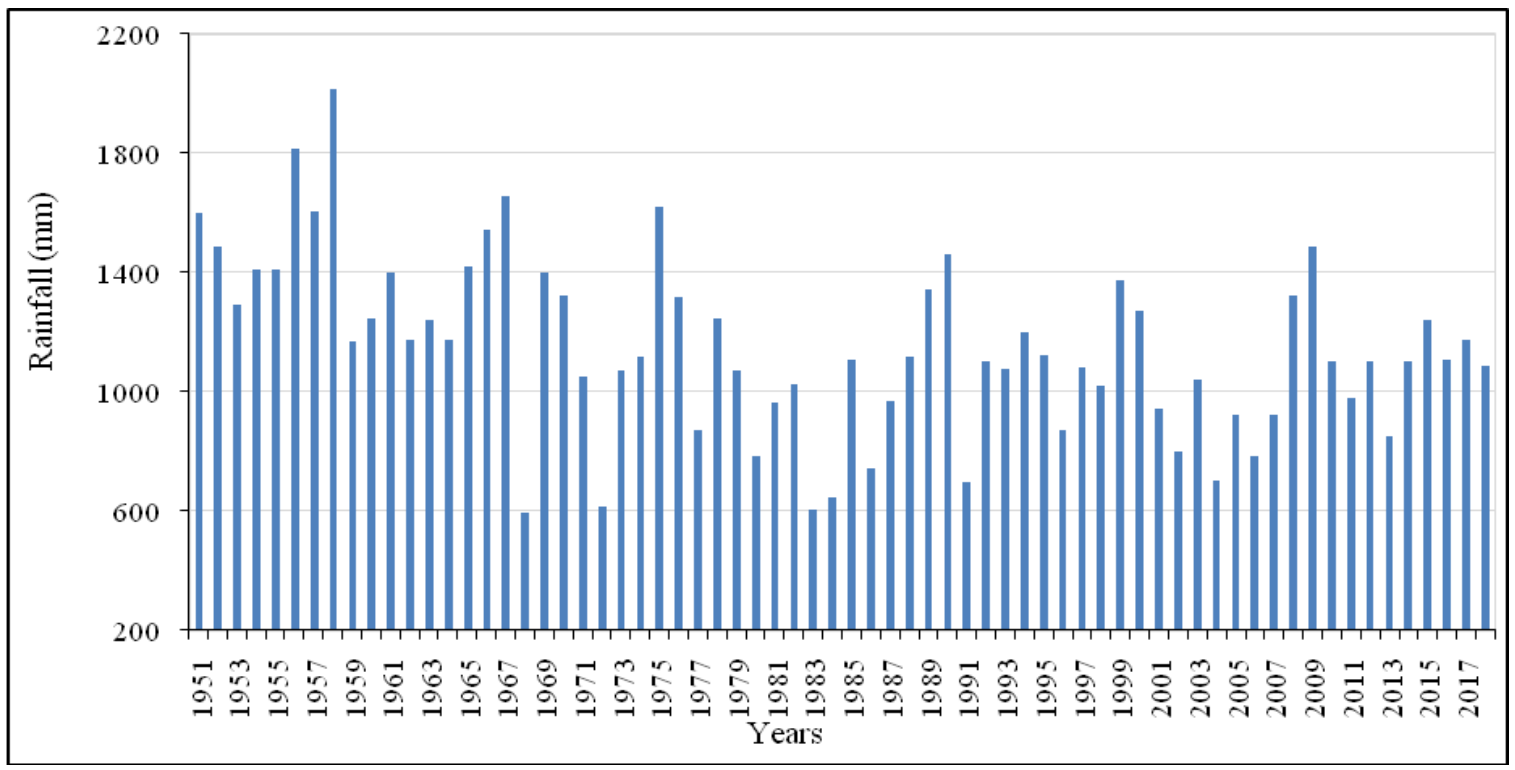

Figure 2. Interannual evolution of rainfall at the Diouloulou station from 1951 to 2018.

\section{MATERIALS AND METHODS}

The implementation of the RUSLE model required a lot of spatial reference data from different sources. The data used in this study are derived from several global databases at varying scales. This is CHIRPS data over a period of more than 20 years for the generation of rain aggressiveness, FAO's soil evasiveness database (factors K), the USGS numerical terrain model from the USGS platform used to calculate the slope (LS factor) and the 2018 Landsat OLI image used for land occupancy mapping (factor $\mathrm{C}$ ). These data have been pre-treated, including corrections and treatments related to reference change, re-sample (bringing all factors to $30 \mathrm{~m}$ spatial resolution). They were projected into the WGS 1984 UTM Zone $28 \mathrm{~N}$ projection system.

The Universal Soil Loss Equation is a full-scale model developed in 1960 and updated in 1978 by Wischmeier and Smith. RUSLE predicts the average annual rate of long-term erosion on the slope of a field based on rainfall, soil type, topography, and agricultural practices. The different parameters of the RUSLE model have a spatial character. GIS software such as ArcGis and image processing such as TerrSet-IDRISI are used to process satellite images and map the erosion rate at the basin level. Watershed delineation is based on the Digital Field Model (MNT) SRTM (Shuttle Radar Topograthy Mission) downloaded from the USGS platform.

The Universal Soil Loss Equation is a multiplier function of the five factors that control water erosion that provide an estimate of erosion (A) in tons/hectares/year. These include climatic aggressiveness or erosivity of rains, soil erodibility, slope and slope length, land use and cropping practices. The formula of the equation is expressed at the parcel scale or a slope by the following relationship:

$\mathbf{A}=\mathbf{R} * \mathbf{K} * \mathbf{L S} * \mathbf{C} * \mathbf{P}$

Where $\mathbf{A}$ is the annual rate of soil loss int/ha/year, 
The (R) factor represents the erosivity of the rains. It refers to the detachment power of soil particles. The calculation of this factor based on the universal equation of soil loss is made through the product of kinetic energy (Ec) and the maximum intensity of the rains for 30 minutes (I30), (Wischmeier and Smith, 1978).

$\mathbf{R}=\mathbf{E}^{* \mathbf{I}_{30}}$

However, the difficulty of finding data on kinetic energy (Ec) and maximum rainfall intensity has led some researchers $[11,12,13]$ to create alternative formulas that only take into account average monthly or annual precipitation for determining $\mathrm{R}$ factor. For this study, the formula used to calculate the aggressiveness of the rains is that of [14], which according to him, the average annual erosivity index of Wischmeier is directly related to the average annual rainfall in West Africa. The formula is expressed by the following relationship:

$\mathbf{R}=\mathbf{P i} * \mathbf{0 . 5 0}$

Where Pi represents the average annual rainfall.

This formula applies to relatively long rainfall series (over 20 years old). The climate aggression factor is calculated based on CHIRPS (Climate Hazards Group InfraRed Precipitation with Station) data observed over a 30-year period from 1989 to 2018. They are a set of near-global rainfall data available since 1981 .

The soil's erodibility (K) factor depends on soil texture, amount of organic material, permeability, and soil structure. Soil erodibility is not homogeneous in space and evolves over time: it increases during the rainy season and varies according to soil characteristics. The age of clearing and cropping techniques [15]. The erosion reflects the soil's ability to withstand erosion. It is defined by three major factors of soil resistance to erosion: structural elements (porosity, compactness, permeability, etc.), textural (granulometry, plasticity) and physicalchemical elements (agility, ion richness of water in the soil) [16]. The erodibility is calculated according to the formula established by Wischmeier and Smith (1978):

$\mathrm{K}=2.110^{-4} * \mathrm{M}^{1.14}(12-\mathrm{a})+3.25(\mathrm{~b}-2)+2.5(\mathrm{c}-3)$

With $\mathrm{M}=(\%$ Sandy + limon $)(100-\%$ Clay $)$

$\mathrm{a}=\%$ organic matter,

$\mathrm{b}=$ permeability code,

$\mathrm{c}=$ structure code $[8]$.

The soil erodibility factor is generated using the FAO database. It is a global soil database harmonized in raster format with granulometric analyses and available free of charge. The spatial resolution is about $1 \mathrm{~km}$ with a scale of 1/5.000.000. These soil data tell us about the textural elements of the soil, including the percentage of sand, silt, clay content, percentage of organic carbon and percentage of organic matter in the upper layers of the soil. Apart from these elements that allow us to generate the $\mathrm{K}$ factor, other variables are presented in the data namely soil thickness, lime and gypsum content, sodium exchange percentage, salinity.

The topographic factor (LS) is a dimensionless factor that represents the slope and length of the slope. The gradient remains the parameter that most influences water erosion. The detachment 
and transport of particles depends on the speed of runoff, the length of the slope and the nature and extent of the terrain. The LS factor is used to assess the influence of slope on the rate of erosion. The method consists of calculating the fill sinks, which represents the filling map of the bowls, followed by the direction of flow from each pixel and ultimately the accumulation of water flows. These three elements combined with the slope of the terrain were used to calculate the topographical factor. It is obtained using the following alternative formula of [17].

LS $=(\text { accumulation du débit } * \text { résolution } / 22,1)^{\mathrm{m}}\left(0,065+0,045 S+0,065 S^{2}\right)$.

Where $\mathbf{m}=0.5$ If the slope is $>5 \% ; \mathbf{m}=0.4$ If the slope is between 3.5 and $4.5 \% ; \mathbf{m}=0.3$ If the slope is in the interval 1-3\%; and $\mathbf{m}=0.2$ If the slope is $\langle 1 \%$. S: is the angle of the slope. The Shuttle Radar Topograthy Mission (SRTM) digital field model downloaded from the USGS website was selected for this study.

Soil protection factor $(\mathbf{C})$ is a dimensionless factor that represents vegetation cover. Factor $\mathrm{C}$ is estimated through the Normalized difference vegetation index (NDVI).

$\mathrm{NDVI}=\frac{\text { NIR }-\mathrm{RED}}{\mathrm{NIR}+\mathrm{RED}}$

The standardized vegetation index (NDVI) is established by subtracting from the infrared channel (NIR) with the red channel (RED). The red band (The resulting neo-channel exhibits an increasing gradient of plant activity ranging from black (no cover) to white (exceedingly high chlorophyll activity). The result of an NDVI takes the form of a new image, the value of each pixel being between 0 (bare soil) and 1 (maximum vegetable cover) [18].The NDVI was used to achieve The C-Factor based on the [19] With $\alpha=0.5 \operatorname{And} \beta=1$ :

$$
C=\exp \left(-a \frac{N D V I}{\beta-N D V I}\right)
$$

The C factor is made based on an image Landsat OLI acquired on May 24, 2018. Radiometric and atmospheric corrections were applied to this image to work with true reflectance values and eliminate dark parts of the image due to atmospheric effects and on which radiometric signal detection depends.

Table 1Landsat 8 OLI Sensor Features (Operational Land Imager).

\begin{tabular}{|l|l|l|l|l|}
\hline Sensor & Acquisition Date & Band & Wavelength & Resolution \\
& \multirow{3}{*}{ OLI } & 1-Aerosols & $0.433-0.453 \mu \mathrm{m}$ & \\
\cline { 3 - 4 } & & 2- Blue & $0.450-0.515 \mu \mathrm{m}$ & \\
\cline { 3 - 4 } & 3- Green & $0.525-0.600 \mu \mathrm{m}$ & \multirow{2}{*}{$30 \mathrm{~m}$} \\
\hline
\end{tabular}




\begin{tabular}{|c|c|c|c|}
\hline \multirow[t]{7}{*}{$24 / 05 / 2018$} & 5- NIR & $0.845-0.885 \mu \mathrm{m}$ & \multirow{7}{*}{$\begin{array}{l}15 \mathrm{~m} \\
30 \mathrm{~m} \\
60 \mathrm{~m}\end{array}$} \\
\hline & 6- SWIR 1 & $1.560-1.660 \mu \mathrm{m}$ & \\
\hline & 7- SWIR 2 & $2.100-2.300 \mu \mathrm{m}$ & \\
\hline & 8- Pan & $0.500-0.680 \mu \mathrm{m}$ & \\
\hline & 9- Cirrus & $1.360-1.390 \mu \mathrm{m}$ & \\
\hline & 10- TIR 1 & $10.30-11.30 \mu \mathrm{m}$ & \\
\hline & 11- TIR 2 & $11.50-12.50 \mu \mathrm{m}$ & \\
\hline
\end{tabular}

The factor representing agricultural practices $(\mathbf{P})$, is also unseated and considers anti-erosive farming practices. These practices act as a mitigation of runoff speed and promote infiltration. $\mathrm{P}$ values are about 0.2 for tiered terraces with counter-slope at 1.0 where there are no anti-erosive practices [7]. The land use of the watershed is dominated by vegetation cover and water bodies. Rice farming remains the most common agricultural activity and is sheltered by the low-lying areas. Rice plots are small, flat-topography spaces that hold water for a period. Rice farmers do not use anti-erosive farming practices. Apart from this situation, mapping this factor remains a problem. In the absence of anti-erosive practices as in this case, the value of $\mathrm{P}$ is equal to 1 .

The method is based on quantitative rules of eroded sediments transported to the shoreline. All factors, which are also thematic maps (Figure 4), are brought to the same spatial resolution (same size for all pixels) so that they can be crossed. Reprojections (space reference change) have also been made so that the factors have the same spatial reference and can be superimposed. Reclassification steps are also carried out based on the minimum and maximum amount of information sought. 
ISSN: $2456-8643$

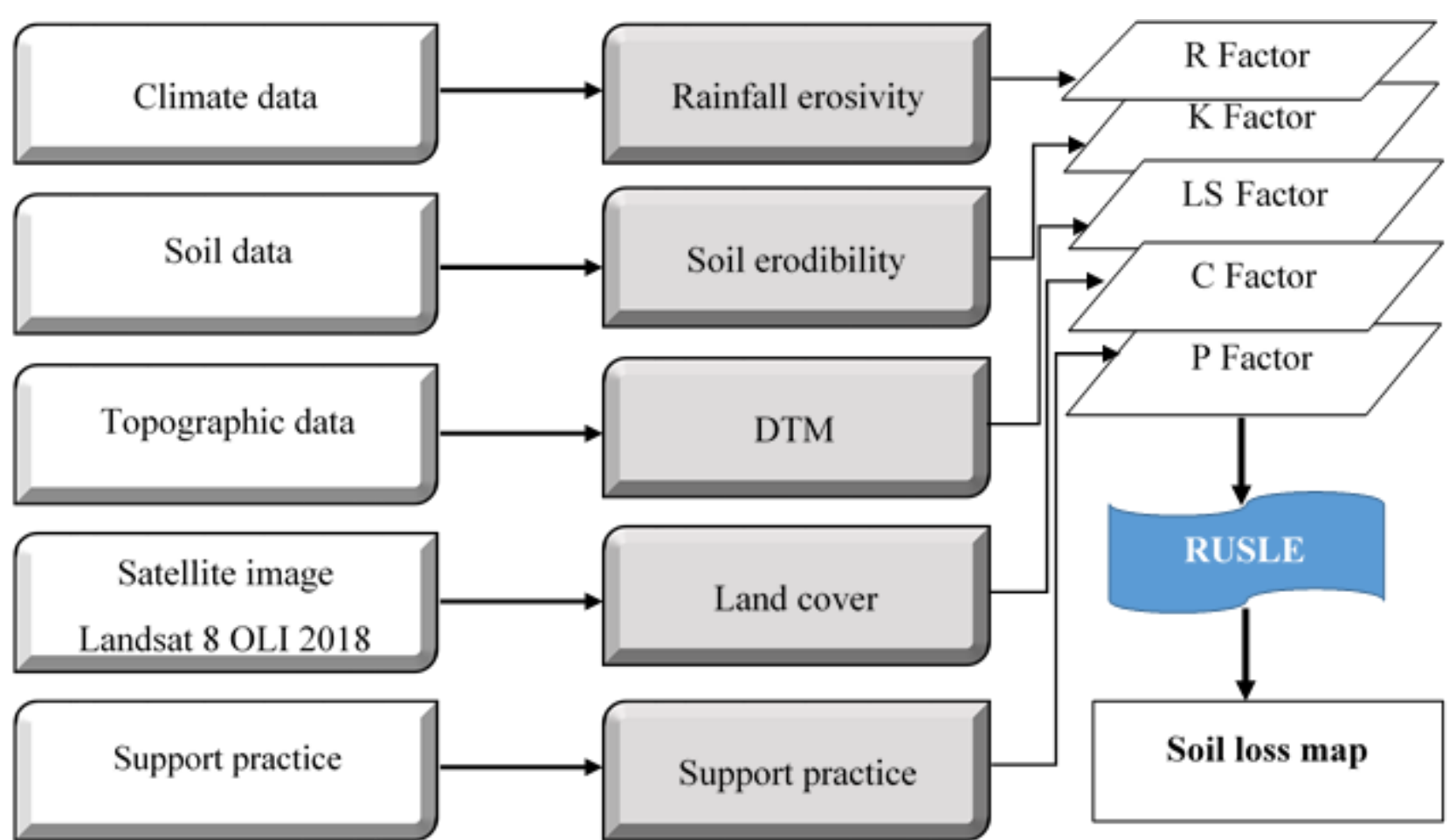

Figure 3: Organization of the treatment chain for estimating the amount of eroded sediment.

\subsection{Sedimentology}

Sedimentological data are extracted and analyzed from the SHOM database, created from its own observations and samples. The description of the data is extracted from the SHOM website (www.shom.fr). Available data range from visual descriptions of sediments over the past 150 years to analyses obtained with the most modern systems (laser micro-granulomeres, core measuring benches, acoustic imaging). The data included in this database relate to the nature of surface sediments, the thickness of loose sediments, and the nature of the bedrock. The main objectives of this Database are to enable the compilation of sedimentological data for the mapping of funds, intended for all uses and the realization of models of sedimentary dynamics and acoustics.

\section{RESULTS}

\subsection{Sedimentary flow and coastal sedimentation}

Sedimentary transit depends on the particle granulometry and the velocity of the river current. The amount of sediment eroded upstream of watersheds in general is not fully transported to the coast. Sorting based on particle size and flow concentration can be done by causing sediment to be deposited on the bottom. During periods of white water (August-September), triage is low due to the abundance of flows and the strength of runoff, unlike in the dry season, where river flows can be marked by large deficits. However, this phenomenon is not often observable due to the geological and soil characteristics that determine the nature of sediments deposited in coastal areas. Suspended sediments carried by rivers are generally clays and fine sands, while sediments 
carried on the bottom are made up of sand and gravel. This hydro sedimentary dynamic controls marine sedimentology (Figure 5). The particles drained by streams are made up globally of fine sands and clays. The sedimentological configuration in the marine environment tells us that fine sands are deposited before clays and that vases are concentrated at the mouth of the Casamance River. Fine sands are sediments containing 50-100\% particles ranging in size from 0.5 to 0.05 millimeters. Clays contain 50-100\% particles smaller than $0.01 \mathrm{~mm}$, while vases contain 20 to $100 \%$ particles less than 0.05 millimeters. This granulometry affects the modes of transport and deposit of sediments.

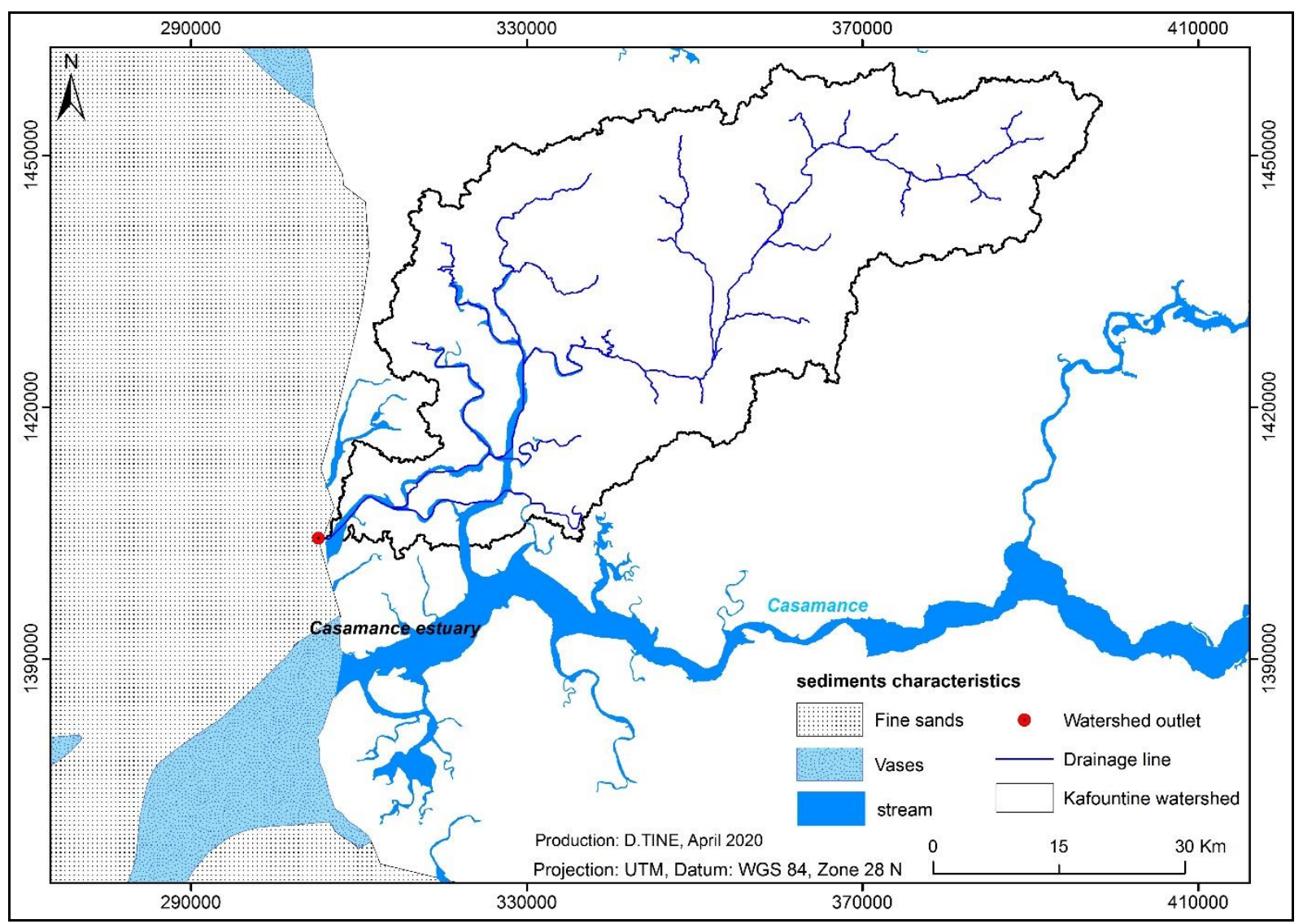

Figure 4: Coastal sedimentology extracted from SHOM's 2013 Global Sedimentary Map

\subsection{RUSLE parameters estimation}

Model estimates only soil losses due to slick erosion and not those that can be caused by other agents. Wischmeier and Smith (1978) proposed it only on a small plot of about $100 \mathrm{~m}^{2}$ or small watersheds. However, equations are often simplified to adapt to other climate contexts. The reference equations were not used because the environments are not the same. The equations used to calculate the factors are derived from the literature written in a similar context as this one. These formulas have been developed by different authors [14, 7, 17, 19], and allowed researchers to implement the universal equation of soil loss regardless of the geographic space considered. The quantification of water erosion is based on the crossing of five (5) thematic 
maps. Since the P factor was absent due to the problems mentioned above, we finally crossed four factors (Figure 6) in accordance with the RUSLE model. These factors are analyzed individually to understand their physical characteristics and their contribution to water erosion modeling.
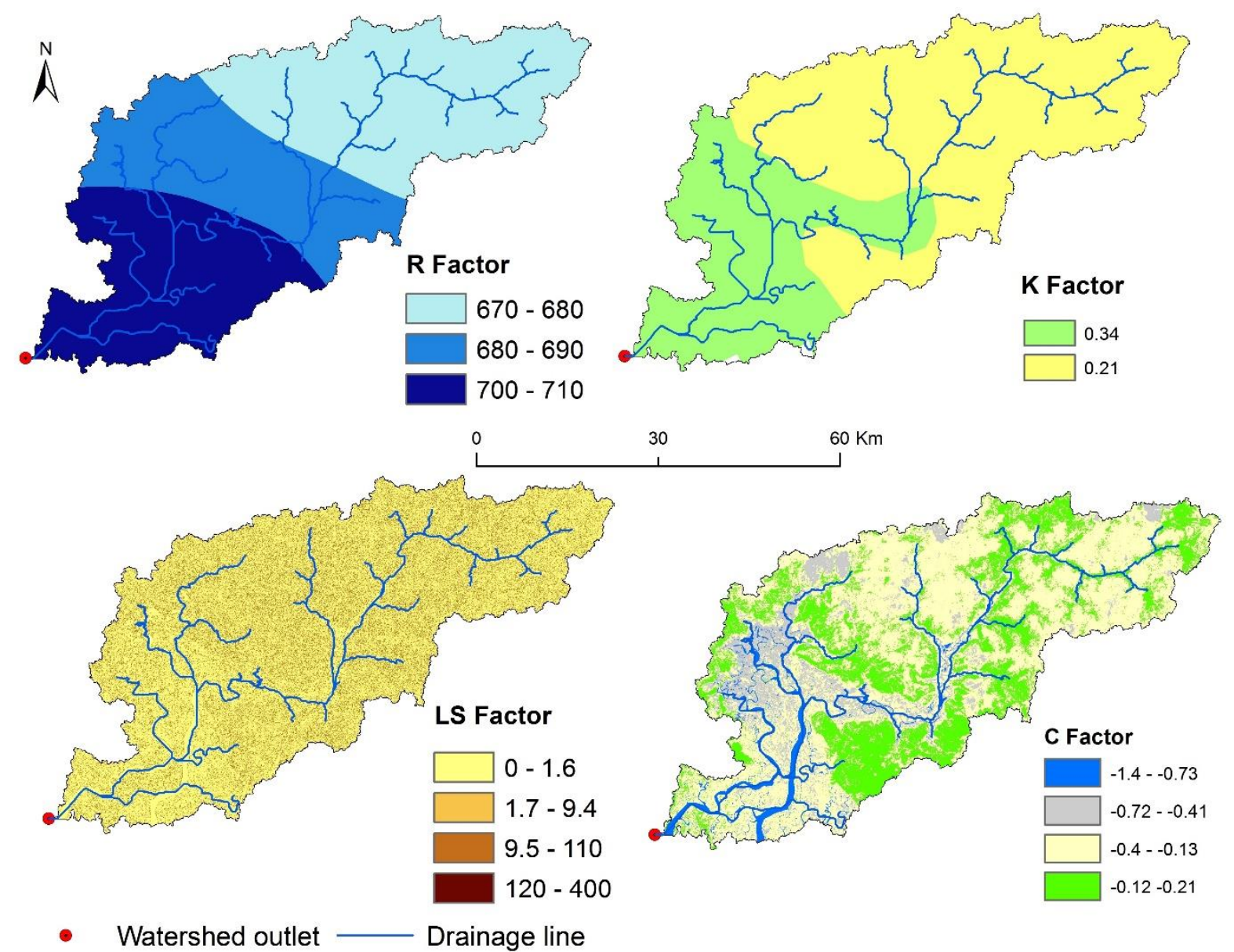

Figure 5: The Four (4) factors used to model water erosion in the Kafountine watershed

\subsection{Analysis of the aggressiveness of the rains}

This (R) factor highlights the spatial distribution of precipitation in the Kafountine watershed. It shows a decrease in rainfall from south to north. This variation is identical to the dynamics of the erosivity of the rains. As a result, there is more aggressiveness in the South, but with fewer impacts due to the physical characteristics of this part. As we move north, climate aggression decreases. It ranges from 710 to $670 \mathrm{MJ} . \mathrm{mm} / \mathrm{ha}$.h.year with an average of $690 \mathrm{MJ} . \mathrm{mm} / \mathrm{ha}$.h.an. These values are generally important for the entire watershed due to the high amount of precipitation recorded by this environment during the rainy season (1200 $\mathrm{mm}$ on average per year).

\subsection{Soil erodibility analysis or $\mathrm{K}$ factor}


The catchment area is covered by two types of soil with an erodibility varying between 0.21 and 0.34 t.ha.h/ha.MJ.mm. The value of the K-factor indicates the soil's resistance to erosion. The analysis of soil erodibility shows that a large part of the catchment area, particularly in the north, is covered by a slightly resistant soil with an erodibility value of 0.21 . The soils in the south of the region are generally hydromorphic. They are more sensitive to water erosion with an erodibility index of 0.34 t.ha.h/ha.MJ.mm.

\subsection{Field gradient analysis or topographical factor (LS)}

The terrain slope index ranges from 0 to 110 . The watershed has an exceptionally low slope of between 0 and 1.6 and represents almost $70 \%$ of its total area. The slope of the land plays an important role in the process of soil water erosion. It facilitates the transport of sediment particles and increases the turbulence of the flow. Exposure to the slope is always crucial in the intensification of erosion. Erosion is less intense on concave slopes than on convex slopes where soil losses are greater [20]. The LS values were grouped into four classes (Figure 5).

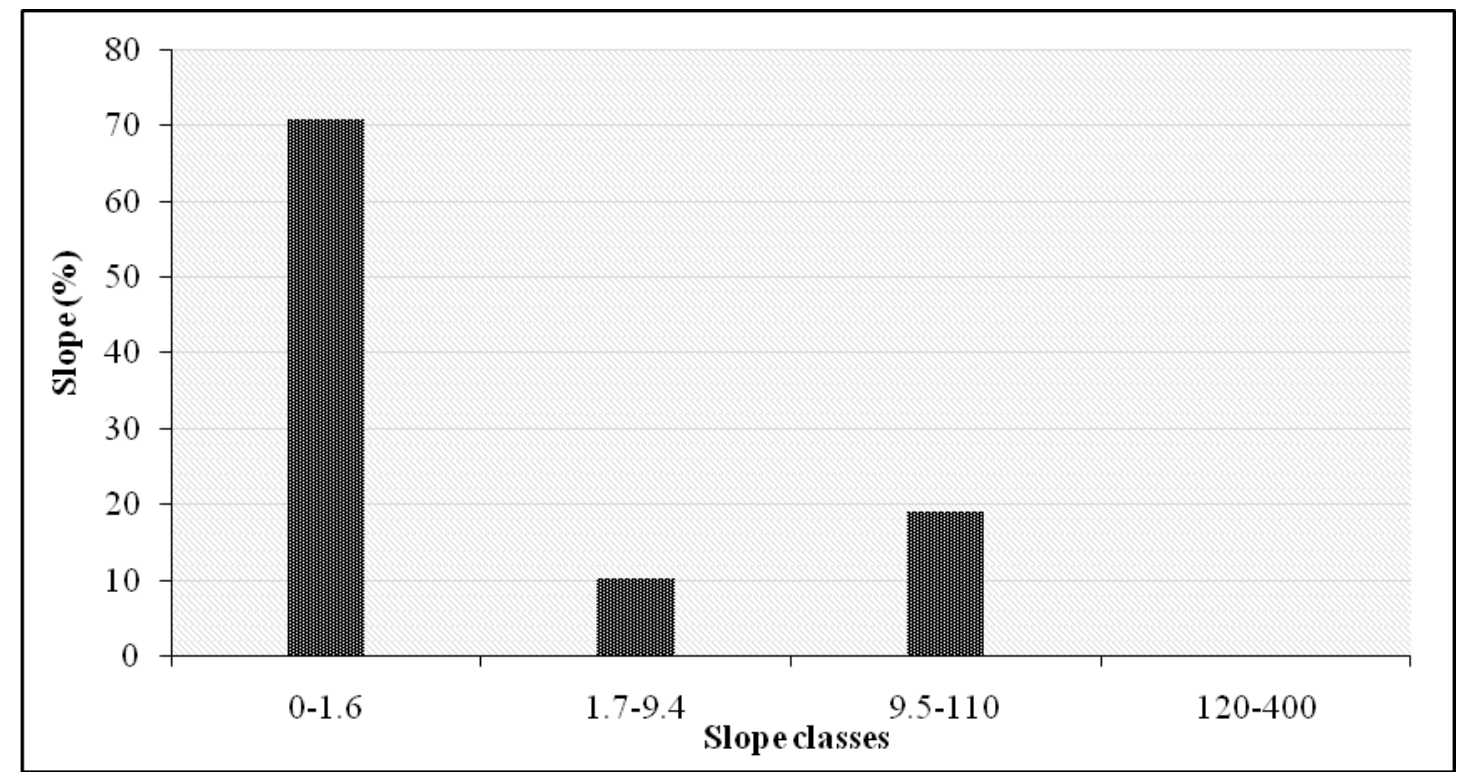

Figure 6: Distribution of LS class in the Kafountine Basin

\subsection{Land and vegetation cover Analysis}

The environment experiences climatic conditions conducive to the development of vegetation cover, which plays a protective role against erosion by reducing beating. The vegetation cover limits runoff and promotes infiltration. C Factor depends on several variables including leaf and branch cover, soil cover, soil biomass that improves water flow into the soil, porosity, surface roughness and soil compaction [21]. The Kafountine watershed is covered by two types of vegetation: continental vegetation that occupies most of the environment and mangrove vegetation found precisely in the estuarine part of the watershed that connects the continent with the sea. Four land-use units were identified after the analysis and reclassification of NDVI values. These are streams with a value between -1.4 and -0.73 , followed by salt land (-0.72 - $0.41)$, then bare soils $(-0.4--0.13)$ and finally vegetation cover with an index between $(-0.12-$ 
0.21). The evolution of vegetation cover is dependent on rainfall. Vegetation is becoming less and less dense, making the soil vulnerable to erosion agents. The area covered by vegetation represents only $25.95 \%$ of the total area of the basin while bare soils dominate with $58.21 \%$. This result tells us that the study area is not sufficiently protected by vegetation against water erosion.

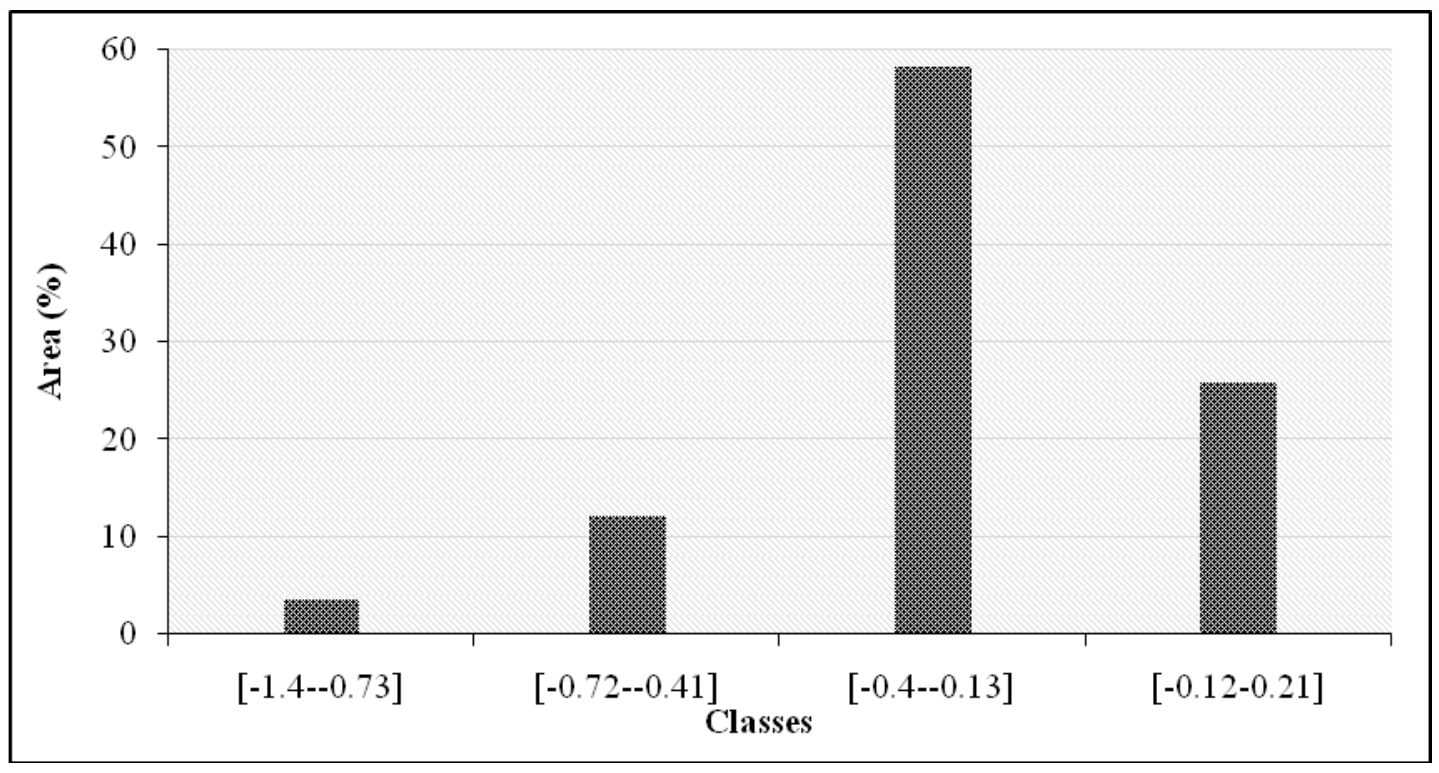

Figure 7: Class of C-factor values in the Kafountine watershed

\section{Potential annual soil erosion estimation}

The methodology adopted in this study allowed us to assess soil losses in the Kafountine watershed in 2018. Integrating data into a geographic information system has also allowed us to structure and prioritize it. The cross-refer to all the thematic maps representing the factors in the universal equation of soil losses of Wischmeier-Smith (1978) and intervening in the process of soil water erosion, provides a map of soil losses at the scale of a pixel over the entire watershed. The result of this cross was classified into five (5) classes to observe spatial variability in soil losses in the study space. The amount of sediment lost varies between 1 and $48 \mathrm{t} / \mathrm{ha} /$ year with an average of about $24.5 \mathrm{t} / \mathrm{ha} /$ year. Analysis of Figure 8 shows that the basin is dominated by classes with low erosion amounts, ranging from 1 to $19.8 \mathrm{t} / \mathrm{ha} /$ year. Heavy sediment losses are located upstream of the watershed and range from 29.2 to $48 \mathrm{t} / \mathrm{ha} / \mathrm{year}$. The lowest losses are recorded at the estuary, sheltered by hydromorphic soils composed of mudflats and salty soil covered in places by mangrove vegetation. Erosion can be zero, given the building blocks of this southern part of the basin. Soil losses vary depending on the slope of the watershed. The highest ground loss values correspond to areas with steep slopes, especially in the north of the study environment. The small localized losses in the estuarine environment correspond to the incredibly low or zero slope classes. In terms of area, estimated losses between 10.4 and 19.8 $\mathrm{t} /$ ha/year cover $25.2 \%$ of the basin area, while $4.4 \%$ of the total area of the basin recorded the largest soil losses. In sum, 83.9\% of the land area loses between 1 and $19.8 \mathrm{t} / \mathrm{ha} /$ year. 


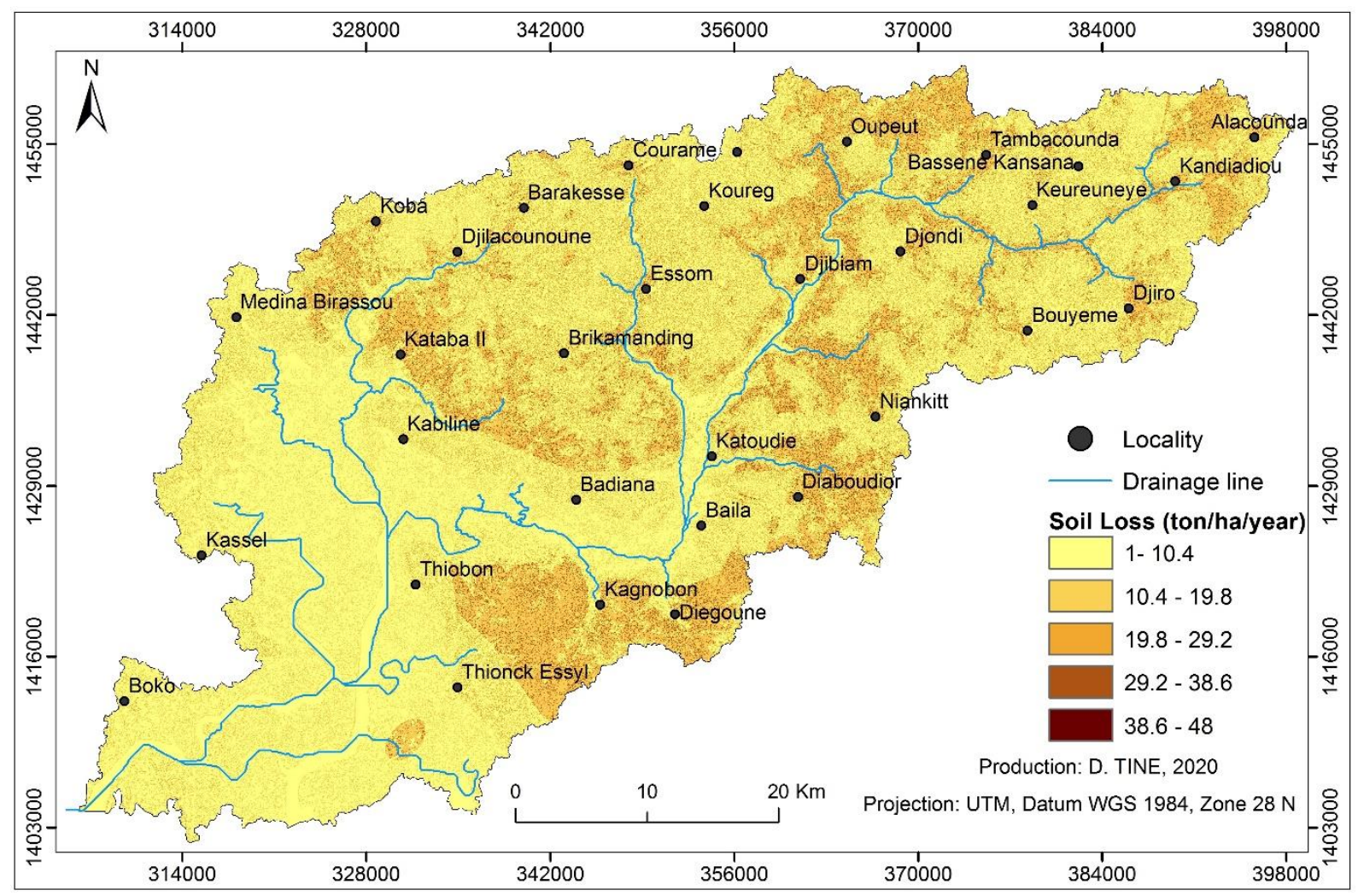

Figure 8: Map of soil losses per t/ha/year in the Kafountine watershed.

\section{DISCUSSION}

The Kafountine watershed is drained by several 'bolongs'that flow into the Atlantic Ocean. These streams drain sediment particles from upstream of watersheds and deposit them in estuaries and beaches to meet river and marine currents. External sediment inputs play a key role in coastal erosion and fattening processes [22, 3, 5]. River sedimentary inputs and alternating erosion and deposit processes are a sedimentary capital that stabilizes the coasts. These sedimentary flows follow a seasonal rhythm, characterized by a strong supply of rainy seasons and a reduction in sediments amounts during the non-rainy season. The amount of sediment deposited by rivers and streams depends essentially on climatic factors. Sedimentary inputs of river origin are conditioned by rainfall, watershed extension, morphology, and lithological and soil nature [23]. These sediments, subjected to a contrast of water density, are deposited on either side of the estuaries and form sandbanks and shorelines. These materials play an especially important role in the sedimentary morphodynamics of the coastline concerned. The spatial analysis of the concentration of suspended materials is a fundamental element for river and coastal morphological studies, distinguishing if possible, the carriage that takes place near the bottom, generated by inter-granular collisions [24].

The empirical model of Wischmeier and Smith (1978) applies to the scale of an agricultural plot. However, its use on areas other than crop plots is at the root of the countless problems encountered, such as the accuracy of the results. The water erosion soil loss map shows the 
origin of sedimentary flows that feed beaches and contribute to the morphodynamic's balance. Analysis of the slope map and soil loss map shows that erosion is greater on slopes than in depressions and wetlands. The analysis of the different factors showed that the topography of the basin is relatively low with slight variations upstream. A spatial variability of precipitation is observed with a South-North gradient. Their structure plays an important role in triggering erosion. The region receives an annual average of more than $1000 \mathrm{~mm}$ of generally intense precipitation, which can lead to strong erosion of the slopes. The geological nature also influences erosion. It produces a pedological support composed of sand, clay and limestone-marl which is sensitive to erosion. Two types of soil form the lithology of the basin with average erodibility. A large part of the catchment area is bare soil followed by plant cover, the rest being water and saline soil. It is important to note that the degradation of vegetation cover under the influence of climate change makes soils vulnerable to aggressive rains and therefore there may be a change in surface horizons. It would therefore be interesting to have up-to-date data on granulometry based on the different land use units [25]. The results show that watersheds are true conveyors of sediment to the shoreline. Sedimentological analyses (Figure 4) show the nature of sediments washed away by storm and river water. They are usually made up of sands, silts, and clays. This sedimentological material transported by suspension is the primary cause of coastal accretion [26].

\section{CONCLUSION}

This work presents the results of a first application of the universal soil loss equation, otherwise called the RUSLE model, in the Kafountine watershed. It allowed us to estimate the amount of sediment removed and transported by runoff and to identify the areas most affected. Quantifying sediments from soil erosion is a key piece of information in the functioning of the watershed. The implementation of the RUSLE model allows the assessment of watershed inputs in coastal fattening processes. These inputs contribute to coastal morphodynamics and limit coastal erosion. The accumulations that water erosion promotes, show along the coast of Casamance morpho-sedimentary units called sandy arrow (the peninsula of birds, river with oysters, point of "Diogué", arrow of Cape Roxo ...). With the persistence of climate change combined with other factors such as lithological nature and the degradation of vegetation cover, soils in this part of the Southern Rivers are becoming increasingly vulnerable to water erosion. It is important to note that not all particles detached by stormwater are deposited in coastal areas. These sediments, whose mode of transport depends on granulometry, can be deposited along the way. Ultimately, the limitations of the model in this study lie in the accuracy of the data used and the complexity of their validation. For a more accurate study, it would be important to use remarkably high spatial resolution data combined with in situ measurements.

\section{REFERENCES}

[1] Borges A. L. O. «Modélisation de l'érosion sur deux bassins versants expérimentaux des alpes du sud », thèse de doctorat, Université Joseph Fourier - Grenoble I : 259p, 1993.

[2] GIEC «Bilan 2007 des changements climatiques : Rapport de synthèse » : 114p, 2007. 
[3] Sadio M. « Morphodynamique et aménagement des flèches littorales de la côte du Sénégal », Thèse de doctorat, UCAD ; AIX Marseille Université : 375p, 2017.

[4] Bilongo A. M. M. «La modélisation génétique de systèmes fluviatiles méandriformes: exemple du bassin de Loranca (Espagne) », Mémoire de stage, Université Pierre et Marie Curie : 39p, 2008.

[5] Thior M., Sané T., Sy O., Descroix L., Ndiaye L. G., Solly B., Cissokho D., and Sambou A. K. «Caractéristiques granulométriques et dynamique sédimentaire entre les différentes unités géomorphologiques du littoral de la Casamance (Sénégal), », Revue Ivoirienne des Sciences et Technologie., $33: 22$ p, 2019.

[6] Wall, G. J., Coote D. R., Pringle E. A., and Shelton I. J., (Eds) «RUSLE-CAN - Équation universelle révisée des pertes de sol pour application au Canada. Manuel pour l'évaluation des pertes de sol causées par l'érosion hydrique au Canada», Direction générale de la recherche, Agriculture et Agroalimentaire Canada, $\mathrm{N}^{\circ}$ de la contribution AAC2244F : 117p, 2002.

[7] Wischmeier, W. H. and Smith D. D. «Predicting Rainfall Erosion Losses - A Guide to Conservation Planning», USDA handbook No. 537. U.S. Department of Agriculture in cooperation with Purdue Agricultural Experiment Station, 1978.

[8] Sadiki, A., Bouhlassa, S., Auajjar J., Faleh A. and Macaire J. J. «Utilisation d'un SIG pour l'évaluation et la cartographie des risques d'érosion par l'Equation universelle des pertes en sol dans le Rif oriental (Maroc) : cas du bassin versant de l'oued Boussouab ». Bulletin de l'Institut Scientifique, Rabat, section Sciences de la Terre, n²6 : pp. 69-79, 2004.

[9] Niang-Diop I. «Érosion côtière sur la Petite Côte du Sénégal à partir de l'exemple de Rufisque. Passé, présent, futur ». Thèse de Doctorat Géologie, Université d'Angers : 475p, 1995.

[10] TINE, D., FAYE, M., Mbaye DIOUf, E., FALL, A. and FAYE, B. Détection de changement d'occupation du sol et analyse de la dynamique des terres salées dans le Département de Foundiougne (Sénégal) : International organization of Scientific Research, 14p, 2020.

[11] Kalman, R. «Le facteur climatique de l'érosion dans le bassin du Sebou, Maroc ». Projet Sebou: 32p, 1967.

[12] Arnoldus, H. M. J. «An Approximation of the Rainfall Factor in the Universal Soil Loss Equation », In: De Boodt, M. and Gabriels D., Eds., Assessment of Erosion. FAO Land and Water Development Division, Wiley \& Sons, Chichester : pp. 127-132, 1980.

[13] Rango, A. and Arnoldus, H. M. J. «Aménagement des bassins versants». Cahiers techniques de la FAO : pp. 1-11, 1987.

[14] Roose, E. «Erosion et ruissèlement en Afrique de l'ouest, vingt années de mesures en petites parcelles expérimentales», travaux et documents de l'ORSTOM Nº78:107p, 1977. 
[15] Roose, E. « Dégradation des terres et développement en Afrique de l'Ouest », Bull. Rech. Agron.Gembloux 20(3/4): 33p, 1985.

[16] Paul-Hus, C. «Méthodes d'étude de l'érosion et gestion des sites dégradés en NouvelleCalédonie », centre universitaire de formation en environnement université de Sherbrooke: 127p, 2011.

[17] The, H. S., Sidek, L. M. and Julien, P. Y. « Soil erosion modeling using RUSLE and GIS on Cameron highlands, Malaysia for hydropower development», RES/The School for Renewable energy science, IS600 Akureyri, Iceland : 76p, 2011.

[18] Bouiadjra, S. E. B., Zerey, W. E. and Benabdeli, K. « Etude diachronique des changements du couvert végétal dans un écosystème montagneux par télédétection spatiale : cas des monts du Tessala (Algerie occidentale) ». pp. 211-225, 2011.

[19] Gitas, I. Z., Douros, k., Minakou, C., Silleos and Karydas, C. G. «Multi-temporal soil erosion risk assessment in N. Chalkidiki using a modified Usle raster model » : 14p, 2009.

[20] Roose, E. «Évolution historique de lutte antiérosive. Vers la gestion conservatoire de l'eau, de la biomasse et de la fertilité des sols : (GCES) ». Bulletin Réseau Erosion 19 : pp. 11-25, 1999.

[21] Raïssouni, A. «Modélisation et cartographie de la sensibilité et de l'aléa d'érosion des sols à l'échelle régionale par USLE et SIG (Rif Nord occidental, Maroc) ». Thèse de Doctorat EsSciences, Fac. Sci. Tech. Tanger, Maroc : 208p, 2012.

[22] Faye, I. « Dynamique du trait de côte sur les littoraux sableux de la Mauritanie à la GuinéeBissau (Afrique de l'ouest) : approche régionale et locale par photo-interprétation, traitement d'images et analyses de cartes anciennes ». Thèse de doctorat, Université de Bretagne occidentale: 321p, 2010.

[23] UICN. «Conserver la biodiversité ... pour le bien-être des populations locales » : 32p, 2010.

[24] Amoussou, E. «Variabilité pluviométrique et dynamique hydrosédimentaire du bassinversant du complexe fluvio-lagunaire Mono-Ahémé-Couffo (Afrique de l'Ouest) », thèse de doctorat, Université de Bourgogne : pp. 83-85, 2010.

[25] Payet, E., Dumas, P., Pennober, G. «Modélisation de l'érosion hydrique des sols sur un bassin versant du sud-ouest de Madagascar, le Fiherenana », VertigO - la revue électronique en sciences de l'environnement, Volume 11 Numéro 3, 2011.

[26] Salomon J. N. «L'accrétion littorale sur la côte Ouest de Madagascar : 35-59 », 2009. 